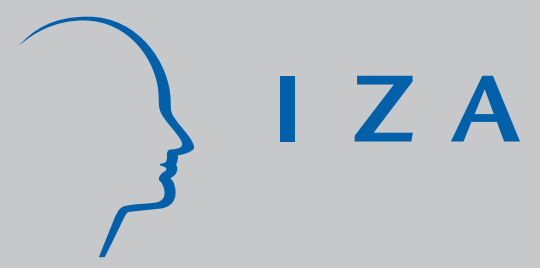

IZA DP No. 1253

Geographic Labour Mobility and Unemployment Insurance in Europe

Konstantinos Tatsiramos

August 2004 


\title{
Geographic Labour Mobility and Unemployment Insurance in Europe
}

\author{
Konstantinos Tatsiramos \\ European University Institute \\ and IZA Bonn
}

\section{Discussion Paper No. 1253 \\ August 2004}

\author{
IZA \\ P.O. Box 7240 \\ 53072 Bonn \\ Germany \\ Phone: +49-228-3894-0 \\ Fax: +49-228-3894-180 \\ Email: iza@iza.org
}

\begin{abstract}
Any opinions expressed here are those of the author(s) and not those of the institute. Research disseminated by IZA may include views on policy, but the institute itself takes no institutional policy positions.

The Institute for the Study of Labor (IZA) in Bonn is a local and virtual international research center and a place of communication between science, politics and business. IZA is an independent nonprofit company supported by Deutsche Post World Net. The center is associated with the University of Bonn and offers a stimulating research environment through its research networks, research support, and visitors and doctoral programs. IZA engages in (i) original and internationally competitive research in all fields of labor economics, (ii) development of policy concepts, and (iii) dissemination of research results and concepts to the interested public.
\end{abstract}

IZA Discussion Papers often represent preliminary work and are circulated to encourage discussion. Citation of such a paper should account for its provisional character. A revised version may be available directly from the author. 
IZA Discussion Paper No. 1253

August 2004

\section{ABSTRACT \\ Geographic Labour Mobility and Unemployment Insurance in Europe*}

Conventional wisdom suggests that unemployment benefits create a stronger geographic attachment by lowering the willingness of the unemployed to accept job offers. We assess empirically the effect of benefits on geographic labour mobility using individual data from the European Community Household Panel for France, Germany, Spain, and the UK. Contrary to the conventional wisdom, we find that receiving benefits enhances mobility offsetting the negative effect of benefits on the incentives to move. We estimate binary choice panel data models controlling for unobserved heterogeneity using random and fixed effects. The results are invariant to the estimated model.

JEL Classification: J61, J65, C23, C25

Keywords: geographic labour mobility, unemployment insurance, discrete choice panel data

Konstantinos Tatsiramos

European University Institute

Villa San Paolo

Via della Piazzuolla 43

50133 Florence

Italy

Email: Konstantinos.Tatsiramos@iue.it

\footnotetext{
* I wish to thank Andrea Ichino, Jan van Ours, Karl Schlag, and Francis Vella for valuable suggestions and comments. This paper has also benefited from discussions with Gosta Esping-Andersen, Ludovic Renou, and seminar participants at the European University Institute, Pompeu Fabra, the 2003 EEA Summer School in London, the 2004 ESPE Conference in Bergen, and the 2004 EPUNet Conference in Berlin. Any remaining errors are only mine. Financial support from the European University Institute, the Greek State Scholarship Foundation (IKY), and the CentER at Tilburg University as a Marie Curie Training Site under contract HPRN-CT-2000-00134, is greatly acknowledged.
} 


\section{Introduction}

The purpose of this paper is to study the extent to which Unemployment Insurance Benefits (UIB) affect geographic labour mobility, that is, the decision to accept a job that requires a residential move within a country.

In the process of European integration geographic labour mobility has increased its importance as a mechanism to absorb regional shocks. This is the case because policy instruments such as inflation differentials and exchange rate realignments are not available in the monetary union. Moreover, attaining higher geographic mobility is considered as one of the ways to achieve the objective of full employment in Europe, as set out at the "Lisbon Strategy" (European Commission, 2001).

Although this increased importance of geographic labour mobility has been recognised, it is a stylised fact that mobility rates in Europe are low. In particular, internal migration rates in 1995 measuring the ratio of gross flows to population are about 0.6 per cent in Spain, 1.2 per cent in Germany, 1.5 per cent in France, while they are much higher, around 2.4 per cent, in the UK and the US (OECD, 2000). Adjustment to regional shocks in Europe has mainly been achieved through changes of unemployment and participation rates and less through mobility (Decressin and Fatas, 1995; Jimeno and Bentolila, 1998). In contrast, in the US, regional labour mobility accounts for a large part of regional adjustment to regional shocks (Blanchard and Katz, 1992).

Although the low mobility of workers across European countries can be attributed to cultural and linguistic differences, these differences cannot explain the low regional mobility rates within countries. Alternative explanations are focusing on institutional characteristics which are claimed to reduce the incentives to move. The most common one refers to the Unemployment Insurance (UI) system. ${ }^{1}$

\footnotetext{
${ }^{1}$ Other explanations focus on labour market regulation such as wage coordination and employment protection legislation (EPL) (Bertola, 1999). Centralised wage negotiations tend to reduce regional wage differentials which are necessary in order to compensate migrants for mobility costs and cost-of-living differentials. Furthermore, labour market rigidities through the EPL imply lower job finding rates due to the increased
} 
The standard result from the theory of job search suggests that unemployment benefits increase the reservation wage and reduce the search effort exerted by benefit recipients lowering the probability to find a job (Lippman and McCall, 1979 ; Mortensen, 1977). Consequently, unemployment benefits are considered to impede geographic mobility because of the stronger geographic attachment that the lower employment prospects create. In particular, Hassler et al. (2001) argue that the difference in the generosity of unemployment benefits between Europe and the US is able to explain the difference in the mobility rates, where Europe is characterised by more generous benefits and lower mobility.

Theoretical work which is questioning the conventional wisdom regarding the disincentive effects of UI has emphasised the positive effect of benefits on search effort. The argument suggests that the increased expenditures allowed when receiving benefits may increase the productivity of the search process (e.g. Barron and Mellow, 1979; Tannery, 1983; Ben-Horim and Zuckerman, 1987).

In this paper, we show that theoretically the effect of benefits on geographic labour mobility is ambiguous under the assumption that unemployment benefits relax the financial constraints faced by the unemployed because of the costs associated with a move. There are two forces moving in opposite directions. On the one hand, benefits reduce the opportunity cost of rejecting a job offer which makes the unemployed rejecting more often by choosing a higher reservation wage. On the other hand, higher benefits relax the liquidity constraints which impede mobility making recipients more willing to accept a job offer which requires a move.

From the empirical point of view, the argument that unemployment insurance deters mobility and that its generosity can be accounted for the low regional mobility in Europe has not been established empirically. ${ }^{2}$ This paper offers an empirical assessment of the

hiring and firing costs. This is expected to have an effect also on the employment prospects of the migrants.

${ }^{2}$ The literature has focused on the relation between labour market status and geographic mobility showing that the unemployed are more likely to move relative to the employed. For instance, Da Vanzo (1978) for the US, Pissarides and Wadsworth (1989) for the UK, Antolin and Bover (1997) for Spain. Reviews of the literature on migration can be found in Greenwood (1997), and Herzog et al. (1993). 
effect of UIB on geographical labour mobility in Europe employing individual data from the European Community Household Panel (ECHP) for the years 1994 to 2001. The ECHP is a survey based on a standardised questionnaire that involves annual interviewing of a representative panel of households and individuals in each EU country. The advantage of using the ECHP, in addition to providing longitudinal data, is that persons who move, form or join new households are followed up at their new location. Moreover, the standardised methodology and procedures yield comparable information across countries.

The empirical analysis is based on a sample of males who are labour force participants for France, Germany, Spain, and the United Kingdom (UK). These countries are chosen because they have comparable size both in terms of population and geography and they provide different configuration of labour market institutions. In particular, France, Germany, and Spain, are characterised as more generous in terms of unemployment insurance compared to the UK.

We estimate a binary choice model to identify the determinants of mobility accounting for endogeneity of the regressors with unobserved individual heterogeneity, following Chamberlain (1980). Due to the low inter-regional mobility rates we consider both intra and inter-regional moves. To distinguish between a move related to housing or personal reasons and a job related move, we define as movers those who have moved and have obtained a new job.

We find that receiving unemployment benefits does not create an adverse incentive effect on the probability to move for a new job. In statistical terms, there is no significant difference in the likelihood to move between recipients and non-recipients. The only exception is Germany, in which recipients are less likely to move relative to non-recipients. Although recipients face lower probabilities relative to non-recipients in Germany, the results are not compatible with the idea that a more generous UIB system lowers mobility. In particular, we find that recipients face the lowest probability to move in the UK, which provides with the 
least generous benefits among the countries in the study. These results indicate, contrary to the conventional wisdom, that receiving benefits enhances mobility offsetting the negative effect of benefits on the incentives to move.

Related work by Ahn et.al. (1999), using Spanish data on the willingness to move for work (but not on actual individual migration), shows, as we do in our study, that there is no significant difference on migration willingness between recipients and non-recipients. Goss and Paul (1990), use information on unemployment benefits and actual individual migration for a sample of heads of households from the PSID for the US. They also do not find a significantly different effect between recipients and non-recipients on the probability to move, although they find that those recipients who are involuntarily unemployed are less likely to move, while those recipients who are voluntarily unemployed are more likely to move, relative to the non-recipients. The result for the involuntary unemployed is related to the probability of recall from the previous employer for the recipients of unemployment insurance, which reduces the incentives to move.

The rest of the paper is organised as follows. Section 2, discusses the theoretical framework, while Section 3 describes the data and the institutional features of the countries used in the empirical analysis. The econometric methodology is discussed in Section 4 and the results of the empirical analysis in Section 5. The conclusions of the study are drawn in Section 6 .

\section{Theoretical Framework}

Using the standard model of job search (see for example Lippman and McCall, 1979), we study the effect of unemployment benefits on the exit rate from unemployment to a job which requires a move, allowing for a substitution effect between benefits and mobility cost. Since mobility cost is binding only in the national market, we focus on job offers which require a move. 
We consider an infinitely lived individual who maximises the discounted value of lifetime income, $E\left\{\sum_{t=0}^{\infty} \beta^{t} y_{t}\right\}$, where income at time $t, y_{t}$, is equal to the wage rate $w_{t}$ for employed workers and to a benefit $b_{t}$ for unemployed. The following standard assumptions are made:

Both the wage and the benefit are constant over time. Unemployed can receive at most one wage offer $w$ at each period $t$. The wage offer $w$ is the realisation of a random variable $\widetilde{w}$ which is drawn from the known distribution $F$ on $[0, \bar{w}]$, with $\bar{w}$ denoting the maximum attainable wage and $F(\bar{w})=1$. Offers are assumed to arrive at an exogenous rate $1 \geq \lambda>0$. Both the arrival rate and the distribution of offers are time invariant.

An unemployed who has received a job offer with probability $\lambda$ has the option either to accept the job and work at the specified wage $w$, or to reject and wait for a better offer in next period. If an offer is accepted then the job lasts forever, that is, no firing or quit is allowed. Accepting a job offer that requires a move involves some cost $c(b)$, which is assumed to be a function of the benefits, such that, $c(0)=\widetilde{c}>0$ and $c^{\prime}(b)<0$, for $b>0$. Thus, it is assumed that the mobility cost is a decreasing function of the benefits. For those receiving no benefits the cost is equal to $\widetilde{c}$.

We denote the value of accepting and being employed as

$$
V_{a}(x)=\sum_{t=0}^{\infty} \beta^{t} x-c(b)=\frac{x}{1-\beta}-c(b)
$$

which is an increasing function of the wage.

In every period, an unemployed has income $b$, receives an offer with probability $\lambda$, and chooses the action that yields the highest value. With probability $(1-\lambda)$, the unemployed receives no offer and remains unemployed. The value of being unemployed is therefore defined by

$$
V_{r}=b+\beta\left\{\lambda E\left\{\max \left[V_{a}(w), V_{r}\right]\right\}+(1-\lambda) V_{r}\right\}
$$

which can be written as 


$$
(1-\beta) V_{r}=b+\beta \lambda \int_{w^{R}}^{\bar{w}}\left[V_{a}(w)-V_{r}\right] d F(x)
$$

where $w^{R}$ denotes the cutoff strategy of the unemployed. The value of rejecting and remaining unemployed, $V_{r}$, is independent of the wage offer that has been received. The optimal reservation wage is derived by maximising equation (3) with respect to $w^{R}$ and is such that

$$
V_{a}\left(w^{R *}\right)=V_{r}
$$

That is, the optimal reservation wage is the wage at which the unemployed is indifferent between accepting or rejecting an offer. Any wage offered which is higher than the reservation wage is accepted. Using equations (1) and (3), the optimal condition of equation (4) can be written as

$$
w^{R *}=b+c(b)(1-\beta)+\frac{\beta}{1-\beta} \lambda \int_{w^{R *}}^{\bar{w}}\left(w-w^{R *}\right) d F(x)
$$

Using equation (5), we can do comparative statics by defining the function

$$
H\left(w^{R *}, b, \widehat{c}, \lambda, \beta\right)=w^{R *}-b-\widehat{c}(1-\beta)-\frac{\beta}{1-\beta} \lambda \int_{w^{R *}}^{\bar{w}}\left(w-w^{R *}\right) d F(x)
$$

where $\widehat{c}=c(b)$ and compute the partial derivatives

$$
\begin{aligned}
H_{w^{R *}} & =1+\frac{\beta}{1-\beta} \lambda\left[1-F\left(w^{R *}\right)\right]>0 \\
H_{b} & =-1-(1-\beta) c^{\prime}(b) \lesseqgtr 0 \\
H_{\widehat{c}} & =-(1-\beta)<0
\end{aligned}
$$

By the implicit function theorem we obtain that 


$$
\frac{\partial w^{R *}}{\partial b}=-\frac{H_{b}}{H_{w^{R *}}}, \text { and } \frac{\partial w^{R *}}{\partial \widehat{c}}=-\frac{H_{\widehat{c}}}{H_{w^{R *}}}
$$

From equation (6), since $H_{w^{R *}}>0$ and $H_{\widehat{c}}<0$, then $\frac{\partial w^{R *}}{\partial \widehat{c}}>0$. Therefore, higher mobility cost, keeping benefits fixed, leads to higher reservation wage since the opportunity cost of rejecting any offer is lower. In other words, mobility cost makes unemployed more reluctant to accept a job offer.

The effect of benefits on the reservation wage is ambiguous and depends on the sign of $H_{b}$ in equation (6). If

$$
c^{\prime}(b)<-1 /(1-\beta) \text { or }\left|c^{\prime}(b)\right|>|1 /(1-\beta)|
$$

then $H_{b}>0$ and therefore, $\frac{\partial w^{R *}}{\partial b}<0$ since $H_{w^{R *}}>0$ from equation (6). That is, if benefits lower the mobility cost more than they increase the value of being unemployed, this leads to a lower reservation wage since the opportunity cost of rejecting an offer is increased.

Thus, there are two forces moving in opposite directions. On the one hand, higher benefits reduce the opportunity cost of rejecting a job offer which makes unemployed rejecting more often by choosing a higher reservation wage. On the other hand, higher benefits reduce the mobility cost making the unemployed more willing to accept a job offer that requires a move by choosing lower reservation wages.

\subsection{The Escape Rate from Unemployment}

The escape rate from unemployment is defined as

$$
q=\lambda\left[1-F\left(w^{R *}\right)\right]
$$

which is the product of the probability to receive an offer $\lambda$, and the probability to accept an offer $1-F\left(w^{R *}\right)$. A higher reservation wage lowers the probability to accept a job offer 
and the escape rate from unemployment. The standard case without mobility cost shows that benefit recipients choose higher reservation wages, because of lower opportunity cost, leading to lower escape rate from unemployment. In other words, when $c^{\prime}(b)=0$ in equation

(6), then $\frac{\partial w^{R *}}{\partial b}>0$ and $q_{b}<q_{n b}$, where $q_{b}$ and $q_{n b}$ refer to the exit rate for recipients and non-recipients, respectively.

In the presence of mobility cost, the reservation wage is expected to be higher for both recipients and non-recipients in order to compensate for the mobility cost, as shown in

equation (7) since $\frac{\partial w^{R *}}{\partial \widehat{c}}>0$. For the benefit recipients, assuming that $c^{\prime}(b)<0$, the increase of the reservation wage due to the mobility cost will be lower than the one for non-recipients increasing their exit rate from unemployment and thus enhancing labour mobility. That is, the disincentive effect of benefits is partially offset. When equation (8) holds, recipients have lower reservation wage than non-recipients and $q_{b}>q_{n b}$. That is, the exit rate from unemployment for recipients is higher than the one for non-recipients. In this case, the disincentive effect of benefits on the decision to accept a job is totally reversed.

\section{Data Description}

The empirical analysis is based on individual data from the eight waves of the European Community Household Panel (ECHP) for the years 1994-2001. The ECHP is a survey based on a standardised questionnaire that involves annual interviewing of a representative panel of households and individuals in each country covering a wide range of topics: demographics, employment characteristics, housing, education, income, etc. In the first wave, a sample of some 60,500 nationally represented households - approximately 130,000 adults aged 16 years and over - were interviewed in the then 12 Member States. There are three characteristics that make the ECHP relevant for this study. Namely, the simultaneous coverage of employment status and housing situation, the standardised methodology and procedures yielding comparable information across countries and the longitudinal design in which information 
on the same set of households and persons is gathered. The advantage of using the ECHP, in addition to providing longitudinal data, is that persons who move, form or join new households, are followed up at their new location. These features allow a European cross-country comparative study of geographic mobility.

The sample consists of males who are labour force participants between 20 and 65 years old. Labour force participants are defined as those who are employed and those who are not employed, but looking for a job.

Information on geographic mobility is obtained from the questions about the year and the month of moving in the current address and the geography of the move. That is, whether it was a move to the current address from another place within the locality or area, or a move from another area of the country. Due to the low inter-regional mobility observed in most European countries we consider both intra and inter-regional moves. However, by doing so, we combine moves which are related to different reasons, such as housing, personal, or job related reasons. Since our focus is on geographic labour mobility, we define a mover as an individual who has moved within or outside his locality or area starting a new job. The dependent variable is therefore binary, taking the value of 1 if an individual has moved with a new job within the year between two consecutive waves, and 0, otherwise.

It is important to distinguish between the causes and the consequences of a move. Being unemployed or married, may result in a change of residence but can also be the consequence of a change of residence. Therefore, the information for the explanatory variables is obtained from the wave preceding the year of the move. The countries studied are France, Germany, Spain, and the UK. This choice is based on geographic, demographic, and institutional reasons. Concerning geography and demographics, these countries are of comparable size both in terms of population and regions. Concerning institutions, these countries are characterised by a different degree of labour market flexibility and different rules regarding UIB provision. Sample statistics and a description of the characteristics of the UI system for each country 
are presented in the following subsections.

\subsection{Descriptive Statistics}

Table (A1) in the Appendix, contains the descriptive statistics of the sample. Regarding the labour market status of the individuals, 9.74 per cent are unemployed in the total sample, with Spain having the highest rate, 14 per cent, and the UK the lowest, 5.87 per cent. Moreover, 43 per cent of these unemployed are receiving unemployment compensation in the total sample. Across countries, the share of unemployed with benefits varies from 54.36 per cent in Germany and 46.88 per cent in France, to 37.67 per cent in the UK and 34.27 per cent in Spain. Education varies also across countries, with Spain having the highest share of low educated, while the UK has the highest share of individuals having finished higher education. Home ownership rates in the sample reflect the situation in the housing market of each country, with Spain and the UK having the highest ownership rates, while Germany has the highest share in the rental market.

Table (A2), shows mobility rates by country. Columns (1), (3), and (4), are constructed using the ECHP for different definitions of mobility, while Column (2), shows the gross flows of regional mobility for each country using data from the OECD (2000). The two sources of mobility rates are not perfectly comparable since they are based on different definitions and refer to different years in some cases. Nevertheless, it appears that the mobility rates obtained from the ECHP follow the same pattern with the aggregate flow data in Column (2). That is, mobility rates are lower in Spain compared to France, Germany and the UK, with the latter exhibiting the highest mobility rates. However, as discussed above, due to the low regional mobility rates experienced by these countries we will focus the analysis on all the moves combined with the start of a new job, as they appear in Column (4).

Table (A3), presents mobility rates by country and by individual characteristics for movers with a new job. The characteristics refer to the wave before the move took place. 
Column (1), shows that 1.19 per cent of those employed last year have moved within the next year and obtained a new job, while the mobility rate for the unemployed is 2.63 per cent. The unemployed have higher mobility rates relative to the employed in all countries, as can be seen from Column (2)-(6). Mobility rates by benefits status for the unemployed are depicted in the next two rows of Table (A3). For the total sample in Column (1), the mobility rate for benefit recipients is 2.67 per cent relative to 2.59 per cent for non-recipients. Mobility rates for recipients are higher relative to non-recipients in France and Spain, and lower in Germany and the UK. Regarding the other characteristics, married and those having children have lower mobility rates, while higher educated are more mobile. Mobility rates drop as people age. Finally, home owners have lower mobility rates relative to renters.

\subsection{Description of Labour Market Institutions}

\subsubsection{The Unemployment Insurance System}

The key features of the UI system are the amount and the duration of benefits. There is a distinction between UI and Unemployment Assistance (UA). When an individual is either not eligible or no longer eligible for UI, he or she may seek UA benefits.

UK has the lowest replacement ratios of UI, as can be seen in Table (A4). The unemployment benefit in the UK is a flat rate covering 30 per cent of the average wage. The replacement rate for France, Germany, and Spain, is more than double relative to the UK. From Table (A5), the payment of UA is flat in France, Spain, and the UK, and 53 per cent of previous wage in Germany, while in all countries UA is means-tested. Eligibility conditions for both UI and UA vary across these countries in terms of the length of previous employment.

Duration for UI varies by employment record (France, Germany and Spain), and/or by age (France and Germany). France has the highest UI benefit duration (up to 60 months). Duration of UA is indefinite in France, Germany and the UK, while it is provided only for 
6 months in Spain.

\subsubsection{Other Institutions}

Apart from the UI system, there are other labour market institutions which may have an effect on mobility incentives, such as the employment protection and wage negotiations. Table (A7), presents an index of employment protection and an index on centralization of wage negotiations. The labour market in Spain is regarded as the most regulated in terms of employment protection regulations, with the UK being the most flexible. In terms of centralisation, Germany has the most centralised wage bargaining system.

Overall, the pattern that emerges from these characteristics indicates that the UI system is more generous in France, Germany, and Spain, relative to the UK both in terms of the level and the duration of the benefits, and that the former countries impose more strict regulations in the labour market.

\section{Empirical Methodology}

The econometric model is a discrete choice model in which the dependent variable $y_{i t}$ is binary, where $i=\{1,2, \ldots N\}$ refers to the individual and $t=\{1,2 \ldots T\}$ refers to the year. We assume there is an underlying response variable $y_{i t}^{*}$ defined by the regression relationship

$$
y_{i t}^{*}=X_{i t} \beta+c_{i}+\varepsilon_{i t}
$$

where $X_{i t}$ is the vector of individual and household characteristics, and $c_{i}$ is the unobserved individual effect which is time invariant. In practice, $y_{i t}^{*}$ is unobserved. What we observe is the dummy variable $y_{i t}$ which equals to 1 whenever $y_{i t}^{*} \geq 0$, and to zero, otherwise. The latent variable $y_{i t}^{*}$ can be thought as the expected gain from moving during the time period $[t-1, t]$ in order to obtain a new job compared to not moving. When the expected gain is positive then we observe a move, that is, $y_{i t}=1$. 
We estimate two models which differ in their assumptions about the correlation between the unobserved effect $c_{i}$ and the covariates $X_{i t}$. Following Chamberlain (1980), assuming that $c_{i}$ follows a conditional normal distribution with linear expectation and constant variance we allow the unobservable variables to be correlated with some elements of $X_{i t}$ (Random effect probit estimator). A Mundlak (1978) version of this model assumes that $c_{i} \mid X_{i} \sim$ Normal $\left(\psi+\overline{X_{i}} \xi, \sigma_{\alpha}^{2}\right)$, where $\overline{X_{i}}$ is the average of $X_{i t}, t=1, \ldots T$, and $\sigma_{\alpha}^{2}$ is the variance of $\alpha_{i}$ in the equation $c_{i}=\psi+\overline{X_{i}} \xi+\alpha_{i}{ }^{3}$

Assuming the unobserved individual characteristics are fixed for each individual, it is possible to obtain a consistent estimator of $\beta$ without any assumptions about how $c_{i}$ is related to $X_{i}$ (Fixed effect logit estimator). If the probability to move given the observed and unobserved characteristics follows the logistic distribution, then conditioning the likelihood of a sequence of moves for an individual on the total number of periods that the individual has moved results in eliminating $c_{i}$. Maximising this conditional version of the likelihood function eliminates their effect and provides with unbiased and consistent estimates (Chamberlain, 1980).

\section{Empirical Analysis and Results}

Each model is estimated separately by country and by pooling the individual observations for each country. In the pooled estimation we interact the labour market status variables with country dummies. This will provide estimates for the effect of receiving benefits in each country on the probability to move relative to the average employed individual in the sample, restricting the effect of the other characteristics to be constant across countries. The information regarding the labour market status contains a dummy for being unemployed, a dummy for receiving benefits and the unemployment duration of the unemployed. Other

\footnotetext{
${ }^{3}$ In practice, this model is a Random effect probit including as regressors the mean values of the timevarying covariates. [For a detailed discussion, see Wooldridge, (2002)]
} 
regressors included refer to individual and household characteristics, such as, age, level of education, type of housing tenure, spouse's labour market status for those married, the number of children, year and regional dummies. In the pooled sample, a set of country dummies are also used in order to capture country specific effects. A detailed description of the variables can be found in the Appendix.

\subsection{Empirical Results}

Estimated coefficients and standard errors from the random effect probit model (RE) by country are presented in Table (1). Starting from the individual characteristics, higher education has a positive and significant effect on the probability to move in all countries except for Spain, in which the effect is not significantly different from zero. This effect of higher education may be justified by the fact that high educated individuals have access to the national labour market compared to low skilled who tend to search more into the local labour market. Cultural and linguistic regional differences in Spain are particularly important which may explain the insignificant effect for Spain. The effect of age shows that young individuals move more and old move less than the prime age workers, which is the reference group.

Turning to the household characteristics, home owners are less likely to move compared to renters in Germany, Spain and the UK confirming the hypothesis suggested by Oswald (1997), which states that owners are less mobile due to the costs associated with buying and selling their home. For France, the effect is positive but not significant. Those having a spouse, independently of her labour market status, are less likely to move compared to single individuals, while the effect of each additional kid lowers the likelihood to move for a new job.

The parameters for the labour market status show that unemployed in Germany, Spain and the UK, are significantly more likely to move relative to the employed. For France 
the effect is not significantly different from zero. The effect of receiving benefits on the probability to move differs across countries. In particular, it is negative for Germany and the UK, and positive for France and Spain. Testing the statistical significance of the coefficient of receiving benefits, we fail to reject the hypothesis that it is different from zero in France, Spain, and the UK, but it is rejected for Germany. That is, unemployment benefits do not create an adverse effect on the probability to move, except for Germany.

Parameter estimates from the fixed effect model (FE) shown in Table (2) are similar with the results from the random effect model. ${ }^{4}$ The only difference observed is that the positive effect of receiving benefits in France on the probability to move is significantly different from zero, but only at the 10 per cent significance level in the fixed effect model.

Table (3), presents the estimates from pooled country estimations for both models. Column (1) includes dummies for the unemployment status and for receiving benefits for the RE model, and Column (3) for the FE model. In Column (2) and Column (4), we report the coefficients from the interaction of the unemployment and benefit dummy with country dummies. For the specification without country dummies, both the RE and the FE results indicate that unemployed are more likely to move relative to the employed, while unemployment benefits have a negative but not significant effect. From the specification with the country dummies, the results for the effect of unemployment and benefits on the probability to move are similar with the ones obtained from the estimations by country in Table (1) and Table (2). That is, recipients are more likely to move compared to non-recipients in France and Spain, while the opposite holds for the UK and Germany, with the effect for Germany being significantly different from zero.

\subsubsection{Predicted Probabilities}

To obtain a size of the effect of benefits on the likelihood to move we compute the predicted probabilities. The predicted probabilities are based on the estimates from the random effect

\footnotetext{
${ }^{4}$ Characteristics which are time invariant, such as education, are not identified in the fixed effect model.
} 
probit model using a pooled country sample. ${ }^{5}$ In Table (4), the first row refers to the predicted probability for the reference person, while the following rows contain the predicted probabilities for an individual who has the same characteristics as the reference person except the characteristic of the corresponding row.

The reference person is an employed, aged 30-44 years old, single, without children, renter, who is living in the East of France in 1999. The probability of moving with a new job for the reference individual is 5.13 per cent. The probability for individuals with the same characteristics as the reference person who are unemployed for 6 months without benefits are 5.91 per cent in France, 22.8 per cent in Germany, 10.64 per cent in Spain, and 12.85 per cent in the UK. The corresponding probabilities for unemployed with benefits are 10.5 per cent in France, 15.81 per cent in Germany, 12.68 per cent in Spain, and 10.75 per cent in the UK. Unemployed in France have on average the lowest probability to move compared to the rest of the countries, which is mainly due to the low mobility probabilities for those without benefits. In France and Spain, recipients face a higher probability to move relative to non-recipients. The opposite holds for Germany and the UK.

Although recipients face lower probabilities relative to non-recipients in Germany, the results are not compatible with the idea that a more generous UIB system is associated with lower mobility. If this was the case, we would expect the mobility probability for recipients in the UK, which has the least generous UI system, to be the highest among the recipients of the other countries which are characterised by more generous UI systems. However, recipients in the UK face the lowest probability to move.

Column (2) and Column (3), show the probabilities for unemployed with 12 and 24 months of unemployment, respectively. The probability to move declines with unemployment duration. This decline is very small for France, Germany, and Spain. In the UK, unemployed with 12 months experience a decline of around 10 per cent in the probability to

\footnotetext{
${ }^{5}$ We report the probabilities from the pooled sample estimates in order to make comparisons across countries based on the same estimation. Predicted probabilities based on the estimates by country provide a similar picture since the results do not differ qualitatively between the two estimations.
} 
move compared to those with 6 months of unemployment.

\section{Conclusions}

In this paper, we provided an empirical assessment of the effect of unemployment benefits on geographic labour mobility in Europe using individual data from the ECHP. The analysis was based on a sample of males who are labour force participants from France, Germany, Spain, and the UK.

We have found that unemployment benefits do not create an adverse incentive effect on the probability to move. In statistical terms, there is no significant difference in the likelihood to move between recipients and non-recipients. The only exception is Germany, in which recipients are less likely to move relative to non-recipients. Although recipients face lower probabilities relative to non-recipients in Germany, the results are not compatible with the idea that a more generous UIB system is associated with lower mobility. In particular, we found that recipients face the lowest probability to move in the UK, which provides with the least generous benefits among the countries in the study. These results indicate, contrary to the conventional wisdom, that receiving benefits enhances mobility offsetting the negative effect of benefits on the incentives to move. Concerning other important determinants of mobility, the results confirm previous findings in the literature. In particular, higher education enhances mobility, young individuals are more likely and older ones are less likely to move relative to the prime aged, while home ownership, being married, and the number of kids deter mobility.

The exact mechanism through which unemployment benefits enhance mobility incentives cannot be identified within our analysis. Theoretical work questioning the conventional wisdom regarding the disincentive effects of benefits has emphasised the positive effect of benefits on search effort. In particular, it suggests that the increased expenditures allowed when receiving benefits may increase the productivity of the search process. Our suggestion 
is that the ability to cover search and mobility costs related to a move when receiving benefits increases the employment opportunities from distant locations.

\section{References}

Ahn N, de la Rica S, Ugidos, A (1999) Willingness to move for work and unemployment duration is Spain. Economica 66:335-57.

Antolin P, Bover O (1997) Regional migration in Spain: the effect of personal characteristics and of unemployment, wage and house price differentials using pooled cross sections. Oxford Bulletin of Economics and Statistics 59 (2):215-235.

Atkinson A, Micklewright J (1991) Unemployment Compensation and Labor Market Transitions: A Critical Review. Journal of Economic Literature XXIX:1679-1727.

Barron J, Mellow W (1979) Search effort in the labour market. Journal of Human Resources 14:389-404.

Ben-Horim M, Zuckerman D (1987) The effect of unemployment insurance on unemployment duration. Journal of Labour Economics 5(3):386-390.

Bertola G (1999) Labor Markets in the European Union. Background paper for a Lecture at EALE 1999 (Regensburg).

Blanchard O, Katz L (1992) Regional evolutions. Brookings Papers on Economic Activity $1: 1-74$.

Chamberlain G (1980) Analysis of Covariance with Qualitative Data. Review of Economic Studies 47:225-238.

Da Vanzo J (1978) Does Unemployment Affect Migration? Evidence from Micro Data. The Review of Economics and Statistics 60(4):504-514.

Decressin J, Fatas A (1995) Regional Labor Market Dynamics in Europe. European Economic Review 39:1627-55.

European Commission (2001) High Level Task Force on Skills and Mobility, Final report, Brussells.

Goss E, Paul C (1990) The impact of unemployment insurance benefits on the probability of migration of the unemployed. Journal of Regional Science 20:349-58.

Greenwood MJ (1997) Internal migration in developed countries. In Rosenzweig MR, Start O (eds), Handbook of Population and Family Economics, Elsevier, North-Holland, Amsterdam, 647-720.

Hassler J, Mora J, Storesletten K, Zilibotti, F (2001) A positive theory of geographical mobility and social insurance. CEPR Discussion Paper, No. 2964. 
Herzog HW Jr, Schlottmann AM, Boehm TP (1993) Migration as Spatial Job-Search: A Survey of Empirical Findings. Regional Studies 27:327-340.

Jimeno JF, Bentolila S (1998) Regional Unemployment Persistence (Spain, 1976-1994). Labour Economics (5)1:25-51.

Lippman SA, McCall JJ (1979) Studies in the Economics of Search. North Holland, Amsterdam.

Mortensen D (1977) Job Search, the duration of unemployment and the Phillips curve. Industrial and Labor Relations Review 30:505-517.

Nickell SJ, Layard R (1999) Labor Market Institutions and Economic Performance. In: Ashenfelter O, Card D (eds) Handbook of Labor Economics, vol. 3. North-Holland, Amsterdam, 3029-84.

Oswald A (1997) Theory of homes and jobs. University of Warwick, mimeo.

OECD (1996) Employment Outlook, OECD, Paris.

OECD (2000) Employment Outlook, OECD, Paris.

Pissarides C, Wadsworth J (1989) Unemployment and the inter-regional mobility of labour. The Economic Journal 99:739-755.

Tannery F (1983) Search effort and unemployment insurance reconsidered. Journal of Human Resources 18:432-440.

Wooldridge JM (2002) Econometric Analysis of Cross Section and Panel Data. MIT Press, Cambridge, MA. 
Table 1. Random effect probit estimates by country. Coefficients and standard errors

\begin{tabular}{|c|c|c|c|c|}
\hline & France & Germany & Spain & UK \\
\hline \multicolumn{5}{|l|}{ Labour Market Status } \\
\hline Unemployed & $-.030(.223)$ & $.935(.141)^{* * *}$ & $.433(.166)^{* * *}$ & $.536(.198)^{* * *}$ \\
\hline Receiving benefits & $.375(.257)$ & $-.269(.142)^{*}$ & $.078(.174)$ & $-.053(.238)$ \\
\hline Unemployment duration & $-.001(.013)$ & $-.002(.007)$ & $-.001(.007)$ & $-.010(.012)$ \\
\hline \multicolumn{5}{|c|}{ Spouse's Labour Market Status } \\
\hline Unemployed & $-.314(.183)^{*}$ & $-.267(.128)^{* *}$ & $-.784(.158)^{* * *}$ & $-.733(.258)^{* * *}$ \\
\hline Employed & $-.401(.155)^{* * *}$ & $-.298(.106)^{* * *}$ & $-1.01(.150)^{* * *}$ & $-.389(.107)^{* * *}$ \\
\hline Inactive & $-.443(.184)^{* *}$ & $-.414(.157)^{* * *}$ & $-1.05(.154)^{* * *}$ & $-.326(.135)^{* *}$ \\
\hline Number of kids & $-.279(.068)^{* * *}$ & $-.266(.055)^{* * *}$ & $-.563(.053)^{* * *}$ & $-.448(.053)^{* * *}$ \\
\hline \multicolumn{5}{|l|}{ Education } \\
\hline Third level & $.333(.082)^{* * *}$ & $.207(.085)^{* * *}$ & $.060(.075)$ & $.153(.062)^{* *}$ \\
\hline 2nd level of secondary & $.053(.084)$ & $.129(.070)^{*}$ & $-.139(.081)^{*}$ & $.143(.079)^{*}$ \\
\hline \multicolumn{5}{|l|}{ Age Groups } \\
\hline $20-24$ & $.495(.113)^{* * *}$ & $.247(.093)^{* * *}$ & $.220(.100)^{* *}$ & $.547(.079)^{* * *}$ \\
\hline $24-29$ & $.282(.076)^{* * *}$ & $.129(.065)^{* *}$ & $.211(.074)^{* * *}$ & $.247(.069)^{* * *}$ \\
\hline $45-54$ & $-.635(.128)^{* * *}$ & $-.233(.071)^{* * *}$ & $-.422(.114)^{* * *}$ & $-.516(.093)^{* * *}$ \\
\hline $55-65$ & $-1.06(.323)^{* * *}$ & $-.768(.132)^{* * *}$ & $-.990(.238)^{* * *}$ & $-.704(.131)^{* * *}$ \\
\hline House Ownership & $.172(.136)$ & $-.522(.112)^{* * *}$ & $-.326(.109)^{* * *}$ & $-.087(.098)$ \\
\hline Constant & $-2.12(.150)^{* * *}$ & $-2.12(.131)^{* * *}$ & $-2.05(.170)^{* * *}$ & $-1.37(.146)^{* * *}$ \\
\hline Log-Likelihood & -.981 .57 & -1658.16 & -1050.82 & -1588.90 \\
\hline $\ln \sigma_{a}$ & $-1.97(.545)$ & $-2.25(.491)$ & $-2.25(.765)$ & $-1.82(.331)$ \\
\hline$\sigma_{a}$ & $.372(.101)$ & $.323(.079)$ & $.324(.124)$ & $.400(.066)$ \\
\hline$\rho$ & $.121(.058)$ & $.094(.042)$ & $.095(.065)$ & $.138(.039)$ \\
\hline$N$ & 4678 & 5400 & 6281 & 3618 \\
\hline
\end{tabular}

Notes: $* * *, * *$, and $*$, denote significance at the $1 \%, 5 \%$ and $10 \%$ level, respectively.

Each estimation includes year and regional dummies and the mean values of time varying covariates.

The reference groups include: employed, single with no kids, low education level, age 30-45, renters. 
Table 2. Fixed effect logit estimates by country. Coefficients and standard errors

\begin{tabular}{|c|c|c|c|c|}
\hline & France & Germany & Spain & UK \\
\hline \multicolumn{5}{|l|}{ Labour Market Status } \\
\hline Unemployed & $-.326(.473)$ & $1.93(.346)^{* * *}$ & $1.00(.394)^{* *}$ & $1.38(.439)^{* * *}$ \\
\hline Receiving benefits & $1.09(.605)^{*}$ & $-.719(.324)^{* *}$ & $-.118(.423)$ & $-.276(.530)$ \\
\hline Unemployment duration & $.010(.036)$ & $-.012(.019)$ & $-.004(.016)$ & $-.044(.032)$ \\
\hline \multicolumn{5}{|c|}{ Spouse's Labour Market Status } \\
\hline Unemployed & $-.497(.421)$ & $-.446(.299)$ & $-1.26(.397)^{* * *}$ & $-1.21(.563)^{* *}$ \\
\hline Employed & $-.641(.376)^{*}$ & $-.487(.225)^{* *}$ & $-1.99(.414)^{* * *}$ & $-.603(.226)^{* * *}$ \\
\hline Inactive & $-.820(.451)^{*}$ & $-.858(.387)^{* *}$ & $-1.89(.393)^{* * *}$ & $-.540(.296)^{*}$ \\
\hline Number of kids & $-.453(.155)^{* * *}$ & $-.583(.139)^{* * *}$ & $-1.16(.172)^{* * *}$ & $-.740(.119)^{* * *}$ \\
\hline Age & $-.051(.233)$ & $.479(.153)^{* * *}$ & $.394(.262)$ & $-.085(.122)$ \\
\hline Age squared & $-.0002(.003)$ & $-.008(.002)^{* * *}$ & $-.006(.003)^{*}$ & $.001(.001)$ \\
\hline House Ownership & $.406(.281)$ & $-.722(.249)^{* * *}$ & $-.680(.250)^{* * *}$ & $-.151(.187)$ \\
\hline Log-Likelihood & -260.46 & -485.28 & -243.21 & -479.87 \\
\hline Sample Size & 885 & 1772 & 1060 & 1929 \\
\hline
\end{tabular}

Notes: $*,{ }^{* *}$ and ${ }^{* * *}$ denote significance at the $1 \%, 5 \%$ and $10 \%$ level, respectively.

Each estimation includes year dummies. 
Table 3. Random effect probit and fixed effect logit estimates for pooled country sample.

Coefficients and standard errors

\begin{tabular}{|c|c|c|c|c|}
\hline & \multicolumn{2}{|c|}{ Random Effect Probit } & \multicolumn{2}{|c|}{ Fixed Effect Logit } \\
\hline & (1) & $(2)$ & $(3)$ & (4) \\
\hline $\begin{array}{l}\text { Labour Market Status } \\
\text { Unemployed } \\
\text { Receiving benefits } \\
\text { Unemployment duration }\end{array}$ & $\begin{array}{l}.549(.084)^{* * *} \\
-.00004(.090) \\
-.003(.004)\end{array}$ & & $\begin{array}{l}1.06(.188)^{* * *} \\
-.083(.203) \\
-.008(010)\end{array}$ & \\
\hline $\begin{array}{l}\text { Country Interaction Dummies } \\
\text { Unemployed*France } \\
\text { Unemployed*Germany } \\
\text { Unemployed*Spain } \\
\text { Unemployed*UK }\end{array}$ & & $\begin{array}{l}.077(.214) \\
.906(.139)^{* * *} \\
.395(.162)^{* *} \\
.574(.187)^{* * *}\end{array}$ & & $\begin{array}{c}.034(.442) \\
1.72(.343)^{* * *} \\
.829(.345)^{* *} \\
1.39(.398)^{* * *}\end{array}$ \\
\hline $\begin{array}{l}\text { Receiving benefits*France } \\
\text { Receiving benefits*Germany } \\
\text { Receiving benefits*Spain } \\
\text { Receiving benefits*UK }\end{array}$ & & $\begin{array}{l}.308(.249) \\
-.257(.143)^{*} \\
.103(.171) \\
-.106(.229)\end{array}$ & & $\begin{array}{l}.976(.587)^{*} \\
-.628(.325)^{*} \\
.075(.395) \\
-.380(.488)\end{array}$ \\
\hline $\begin{array}{l}\text { Un. duration*France } \\
\text { Un. duration*Germany } \\
\text { Un. duration*Spain } \\
\text { Un. duration*UK }\end{array}$ & & $\begin{array}{l}-.001(.012) \\
-.003(.007) \\
-.001(.007) \\
-.012(011)\end{array}$ & & $\begin{array}{l}.001(.035) \\
-.009(.020) \\
-.004(.015) \\
-.042(.028)\end{array}$ \\
\hline $\begin{array}{l}\text { Spouse's Labour Market Status } \\
\text { Unemployed } \\
\text { Employed } \\
\text { Inactive }\end{array}$ & $\begin{array}{l}-.415(.078)^{* * *} \\
-.462(.059)^{* * *} \\
-.528(.075)^{* * *}\end{array}$ & $\begin{array}{l}-.417(.078)^{* * *} \\
-.465(.059)^{* * *} \\
-.532(.075)^{* * *}\end{array}$ & $\begin{array}{l}-.694(.180)^{* * *} \\
-.767(.131)^{* * *} \\
-.944(.174)^{* * *}\end{array}$ & $\begin{array}{l}-.693(.181)^{* * *} \\
-.771(.132)^{* * *} \\
-.962(.175)^{* * *}\end{array}$ \\
\hline Number of Children & $-.400(.027)^{* * *}$ & $-.398(.027)^{* * *}$ & $-.742(.065)^{* * *}$ & $-.745(.066)^{* * *}$ \\
\hline $\begin{array}{l}\text { Education } \\
\text { Third level } \\
\text { 2nd level of secondary }\end{array}$ & $\begin{array}{l}.131(.035)^{* * *} \\
.045(.035)\end{array}$ & $\begin{array}{c}.131(.035)^{* * *} \\
.043(.035)\end{array}$ & & \\
\hline $\begin{array}{l}\text { Age Groups } \\
20-24 \\
24-29 \\
45-54 \\
55-65\end{array}$ & $\begin{array}{l}.379(.045)^{* * *} \\
.222(.034)^{* * *} \\
-.404(.045)^{* * *} \\
-.784(.079)^{* * *}\end{array}$ & $\begin{array}{l}.384(.045)^{* * *} \\
.220(.034)^{* * *} \\
-.405(.045)^{* * *} \\
-.791(.079)^{* * *}\end{array}$ & & \\
\hline $\begin{array}{l}\text { Age } \\
\text { Age squared }\end{array}$ & & & $\begin{array}{c}.148(.079)^{*} \\
-.002(.001)^{* *}\end{array}$ & $\begin{array}{c}.150(.080)^{*} \\
-.002(.001)^{* *}\end{array}$ \\
\hline $\begin{array}{l}\text { House Ownership } \\
\text { Constant }\end{array}$ & $\begin{array}{l}-.203(.054)^{* * *} \\
-1.90(.064)^{* * *}\end{array}$ & $\begin{array}{l}-.205(.055)^{* * *} \\
-1.90(.066)^{* * *}\end{array}$ & $-.287(.110)^{* * *}$ & $-.291(.111)^{* * *}$ \\
\hline $\begin{array}{l}\text { Log-Likelihood } \\
\ln \sigma_{a} \\
\sigma_{a} \\
\rho \\
N\end{array}$ & $\begin{array}{c}-5491.18 \\
-2.00(.219) \\
.366(.040) \\
.118(.022) \\
19997\end{array}$ & $\begin{array}{c}-5473 . .01 \\
-2.03(.224) \\
.361(.040) \\
.115(.023) \\
19977\end{array}$ & -1581.58 & -1573.94 \\
\hline
\end{tabular}

Notes: ${ }^{* * *},{ }^{* *}$ and ${ }^{*}$ denote significance at the $1 \%, 5 \%$ and $10 \%$ level, respectively. The RE estimation includes regional and year dummies and the mean of time varying covariates. The FE estimation includes year dummies. 
Table 4. Predicted mobility probabilities from the random effect probit model (Pooled sample)

\begin{tabular}{lccc}
\hline \hline Reference person & 5.13 & 5.13 & 5.13 \\
& $\begin{array}{c}\text { 6 months } \\
\text { unemployed }\end{array}$ & $\begin{array}{c}12 \text { months } \\
\text { unemployed }\end{array}$ & $\begin{array}{c}24 \text { months } \\
\text { unemployed }\end{array}$ \\
$\begin{array}{l}\text { Labour market status } \\
\text { Benefits*France }\end{array}$ & 10.50 & 10.36 & 10.08 \\
No Benefits*France & 5.91 & 5.82 & 5.64 \\
Benefits*Germany & 15.81 & 15.34 & 14.43 \\
No Benefits*Germany & 22.8 & 22.22 & 21.07 \\
& & & \\
Benefits*Spain & 12.68 & 12.48 & 12.10 \\
No Benefits*Spain & 10.64 & 10.47 & 10.13 \\
& & & \\
Benefits*UK & 10.75 & 9.41 & 7.11 \\
No Benefits*UK & 12.85 & 11.33 & 8.67 \\
\hline
\end{tabular}

Notes: The reference person is an employed, aged 30-44 years old, single, without children, who is in a rented, or in a rent free house and lives in a country and region with similar characteristics as the Est of France in 1999. 


\section{Appendix: Descriptive Statistics and Institutions}

Table A1. Descriptive statistics. Total sample and by country

\begin{tabular}{|c|c|c|c|c|c|}
\hline & Total & France & Germany & Spain & $\overline{\mathrm{UK}}$ \\
\hline \multicolumn{6}{|l|}{ Labour market status } \\
\hline Employed & 90.26 & 93.87 & 89.05 & 86.0 & 94.13 \\
\hline Unemployed & 9.74 & 6.13 & 10.95 & 14.0 & 5.87 \\
\hline With benefits ${ }^{\mathrm{a}}$ & 43.0 & 46.88 & 54.36 & 34.27 & 37.67 \\
\hline Without benefits ${ }^{\mathrm{a}}$ & 57.0 & 53.12 & 45.64 & 65.73 & 62.23 \\
\hline \multicolumn{6}{|c|}{ Spouse's Labour market status } \\
\hline Unemployed & 8.45 & 7.24 & 13.01 & 9.33 & 1.81 \\
\hline Employed & 39.34 & 47.41 & 43.45 & 22.78 & 47.94 \\
\hline Inactive & 23.93 & 22.11 & 16.31 & 35.09 & 20.76 \\
\hline Having no children & 30.32 & 31.19 & 34.72 & 17.11 & 42.48 \\
\hline \multicolumn{6}{|l|}{ Education } \\
\hline Third level & 29.10 & 24.96 & 25.02 & 22.13 & 50.55 \\
\hline 2nd level of secondary & 33.23 & 36.90 & 57.68 & 19.20 & 13.35 \\
\hline Less than 2nd level & 37.68 & 38.14 & 17.30 & 58.67 & 36.10 \\
\hline \multicolumn{6}{|l|}{ Housing Tenure } \\
\hline Owner & 65.29 & 60.03 & 42.36 & 82.94 & 79.38 \\
\hline Renter & 30.71 & 35.02 & 55.41 & 10.64 & 18.73 \\
\hline Free Rent & 4.00 & 4.95 & 2.23 & 6.42 & 1.89 \\
\hline Mean of Age & 40.32 & 40.95 & 40.70 & 39.90 & 39.63 \\
\hline
\end{tabular}

Table A2. Mobility rates by country (various definitions)

\begin{tabular}{lcccc}
\hline \hline & $\begin{array}{c}\text { Inter-regional } \\
\%\end{array}$ & $\begin{array}{c}\text { Gross Flows } \\
\%\end{array}$ & $\begin{array}{c}\text { Inter-regional }^{\mathrm{a}} \\
\text { with new job }^{\mathrm{a}}\end{array}$ & $\begin{array}{c}\text { Inter\&Intra-regional } \\
\text { with new job }^{\mathrm{a}} \%\end{array}$ \\
\hline France & $1.55(323)$ & 1.49 & $0.38(79)$ & $1.01(211)$ \\
Germany & $0.66(172)$ & 1.24 & $0.20(51)$ & $1.36(354)$ \\
Spain & $0.38(99)$ & 0.60 & $0.12(32)$ & $0.86(225)$ \\
UK & $3.68(640)$ & 2.30 & $0.94(163)$ & $2.37(412)$ \\
\hline Notes: & ${ }^{\text {a }}$ Percent of movers from ECHP and number of moves in parenthesis. Source: Author's calculations. \\
b Ratio of gross flows to population (1995 for France and Italy, 1993 for Germany, 1994 for Spain, \\
and 1998 for the UK) from Table 2.12, OECD (2002)
\end{tabular}


Table A3. Mobility Rates ${ }^{a}$ by country and characteristics

\begin{tabular}{|c|c|c|c|c|c|}
\hline & $\overline{\text { Total }}$ & France & "Germany & Spain & 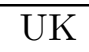 \\
\hline \multicolumn{6}{|l|}{ Labour market status } \\
\hline Employed & 1.19 & 0.91 & 1.09 & 0.75 & 2.28 \\
\hline Unemployed & 2.63 & 2.50 & 3.59 & 1.59 & 3.82 \\
\hline With Benefits ${ }^{b}$ & 2.67 & 2.65 & 3.43 & 1.68 & 3.38 \\
\hline Without Benefits ${ }^{b}$ & 2.59 & 2.33 & 3.78 & 1.54 & 4.08 \\
\hline \multicolumn{6}{|c|}{ Spouse's Labour market status } \\
\hline Unemployed & 1.22 & 1.46 & 1.27 & 0.95 & 1.58 \\
\hline Employed & 1.02 & 0.73 & 1.09 & 0.56 & 1.61 \\
\hline Inactive & 0.65 & 0.63 & 0.52 & 0.35 & 1.60 \\
\hline Having children & 0.80 & 0.68 & 0.94 & 0.48 & 1.41 \\
\hline No children & 2.56 & 1.75 & 2.16 & 2.72 & 3.66 \\
\hline \multicolumn{6}{|l|}{ Education } \\
\hline Third level & 1.61 & 1.67 & 1.15 & 1.04 & 2.29 \\
\hline 2nd level of secondary & 1.33 & 0.84 & 1.48 & 0.78 & 3.23 \\
\hline Less than 2nd level & 1.11 & 0.74 & 1.29 & 0.82 & 2.15 \\
\hline \multicolumn{6}{|l|}{ Age Groups } \\
\hline $20-24$ & 3.56 & 3.82 & 3.03 & 1.46 & 6.80 \\
\hline $25-29$ & 3.04 & 3.26 & 2.75 & 2.07 & 4.71 \\
\hline $30-44$ & 1.30 & 0.93 & 1.45 & 0.94 & 2.06 \\
\hline $45-54$ & 0.43 & 0.15 & 0.78 & 0.23 & 0.64 \\
\hline $55-65$ & 0.21 & 0.05 & 0.24 & 0.06 & 0.57 \\
\hline \multicolumn{6}{|l|}{ Housing Tenure } \\
\hline Owner & 0.81 & 0.46 & 0.49 & 0.61 & 1.69 \\
\hline Renter & 2.39 & 1.90 & 2.04 & 2.53 & 4.88 \\
\hline
\end{tabular}

Note: ${ }^{a}$ All moves with new job. ${ }^{b}$ Percentage of the unemployed with or without benefits.

Source: ECHP, Author's calculations.

Table A4. The unemployment insurance benefits system (UI)

Employment Conditions Replacement Rate

\begin{tabular}{lcc}
\hline France & 4 months in the last 8 months & 75 \\
Germany & 360 days in 3 years & 60 \\
Spain & 12 months in 6 years & 70 \\
United Kingdom & - & $30^{a}$ \\
\hline Source: Table 2.2, OECD (1998), "Benefits Systems and Work Incentives". \\
a From Table 2.1 OECD Employment Outlook (1996), Chapter 2. \\
Applies to a 40-year -old single worker who started work at 18. The replacement rate is expressed \\
as a percentage of previous gross earnings except in Germany where payments are expressed as a \\
percentage of net income.
\end{tabular}


Table A5. The unemployment assistance benefits system (UA)

\begin{tabular}{|c|c|c|c|}
\hline & Employment Conditions & "Replacement Rate & Income/assets test \\
\hline France & $\begin{array}{c}\text { Exhausting UI and } \\
5 \text { years in the last } 10 \text { years }\end{array}$ & flat & Fam/Inc \\
\hline Germany & $\begin{array}{l}\text { Exhausting UI and } \\
6 \text { months in the last year }\end{array}$ & 53 & Fam/Inc \\
\hline Spain & $\begin{array}{l}\text { Exhausting UI, or to } \\
\text { have worked } 6 \text { months }\end{array}$ & flat & Fam/Inc \\
\hline United Kingdom & 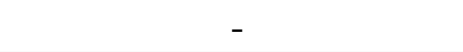 & flat & $\mathrm{Fam} / \mathrm{Inc} / \mathrm{As}$ \\
\hline
\end{tabular}

Source: Table 2.3, OECD (1998), "Benefits Systems and Work Incentives" and

Table 2.3,OECD (2002), "Benefits and Wages".

Applies to a 40-year -old single worker with a long employment history, previously earning

an average income. Fam: Income test includes all family income; Inc: Test for income only;

As: a certain level of assets also disqualifies for UA benefits

Table A6. Duration of UI and UA benefit entitlements in 1996

France: maximum of 27 months insurance (depending on age and employment record) and then maximum of 33 months at declining rate every 4 months

followed by the Allocation de solidarite specifique (unlimited).

Germany: 6-12 or 32 months (depending on age and employment record)

followed by unlimited unemployment assistance.

Spain: 4-24 months insurance (depending on contribution) reducing after 6 months followed by 6 months of unemployment assistance and then social assistance

United Kingdom: 12 months insurance, then unemployment assistance

Source: OECD Employment Outlook 1996, chart 2.3

Table A7. Employment protection and wage bargaining indices Employment Protection $^{\mathrm{a}} \quad$ Centralisation $^{\mathrm{b}}$

\begin{tabular}{lcc}
\hline France & 14 & 7 \\
Germany & 15 & 12 \\
Spain & 19 & 7 \\
United Kingdom & 7 & 6 \\
\hline Source: Nickell\&Layard (1999), Table $6 \& 7 .{ }^{a}$ Country ranking with 20 as the most regulated. \\
b A ranking of the centralisation of wage bargains with 17 being the most centralised
\end{tabular}




\section{Description of the main variables}

\begin{tabular}{|c|c|}
\hline \multicolumn{2}{|l|}{ "Labour Market Status } \\
\hline Unemployed & $\begin{array}{l}\text { Dummy equals } 1 \text { if unemployed and looking for a job, } \\
\text { and } 0 \text { if employed }\end{array}$ \\
\hline Receiving benefits & $\begin{array}{l}\text { Dummy equals } 1 \text { if unemployed and receiving benefits, } \\
\text { and } 0 \text { otherwise }\end{array}$ \\
\hline Unemployment duration & $\begin{array}{l}\text { Months of unemployment at the time of the interview } \\
\text { if unemployed }\end{array}$ \\
\hline \multicolumn{2}{|c|}{ Spouse's Labour market status } \\
\hline Unemployed & Dummy equals 1 if spouse is unemployed, and 0 otherwise. \\
\hline Employed & Dummy equals 1 if spouse is employed, and 0 otherwise \\
\hline Inactive & Dummy equals 1 if spouse is inactive, and 0 otherwise \\
\hline Number of kids & Number of kids in the household \\
\hline \multicolumn{2}{|l|}{ Education levels } \\
\hline Higher level of education & Dummy for having finished higher education \\
\hline Medium level of education & $\begin{array}{l}\text { Dummy for having finished second level of } \\
\text { secondary education }\end{array}$ \\
\hline Lower level of education & $\begin{array}{l}\text { Dummy for having finished less that second level of } \\
\text { secondary education }\end{array}$ \\
\hline Home ownership & Dummy equals 1 for home owners \\
\hline
\end{tabular}

